\title{
Escherichia coli 0157:H7: distribution, molecular characterization, antimicrobial resistance patterns and source of contamination of sheep and goat carcasses at an export abattoir, Mojdo, Ethiopia
}

Solomon Abreham ${ }^{1}$, Akafete Teklu², Eric Cox ${ }^{3}$ and Tesfaye Sisay Tessema ${ }^{4 *}$ (D)

\begin{abstract}
Background: Cattle have been identified as a major reservoir of E. coli O157:H7 for human infection; the ecology of the organism in sheep and goats is less understood. This study was carried out to determine prevalence, source of infection, antibiotic resistance and molecular characterization of Escherichia coli O157: H7 isolated from sheep and goat.

Methods: Systematic random sampling was carried out at Modjo export abattoir, Ethiopia, from November 2012 to April 2013 to collect 408 samples from 72 sheep and 32 goats. Samples collected were skin swabs, fecal samples, intestinal mucosal swabs and the inside and outside part of carcasses as well as carcass in contacts such as workers hands, knife, hook and carcass washing water. Then, samples were processed following standard bacteriological procedures. Non-Sorbitol fermenting colonies were tested on latex agglutination test and the positives are subjected to PCR for detection of attaching and effacing genes (eaeA) and shiga toxin producing genes (stx 1 and stx2). All E. coli O157:H7 isolates were checked for their susceptibility pattern towards 15 selected antibiotics.
\end{abstract}

Results: E. coli O157:H7 were detected in only 20/408 samples (4.9\%). Among these 20 positive samples, 70\% (14/20), 25\% (5/20) and 5\% (1/20) were from sheep, goats and knife samples, respectively. No significant associations were found between carcasses and the assumed sources of contaminations. Of all the 20 isolates virulence genes were found in 10 (50\%) of them; 3 (15\%) with only the eaeA gene and 7(35\%) expressing eaeA and stx2 genes. All the isolates were susceptible to Norfloxacin (NOR) (100\%).

Conclusions: The presence of virulence genes shows E. coli O157:H7 is a potential source of human infection in Ethiopia.

Keywords: Abattoir, Antibiotic sensitivity, CT-SMAC, E. coli O157:H7, IMS, Latex agglutination, Multiplex PCR

\section{Background}

Currently, microbial food borne illness, caused by a wide spectrum of pathogens, is a global concern though extensive scientific progress and technological developments achieved in recent years. Most of microbial pathogens are zoonotic and have reservoirs in healthy food animals from which they spread to an increasing variety of foods. This makes foods of animal origin major

\footnotetext{
* Correspondence: tesfu74@yahoo.com

${ }^{4}$ Institute of Biotechnology, Addis Ababa University, Addis Ababa, Ethiopia Full list of author information is available at the end of the article
}

vehicles of food borne infections [1]. Microbial contamination of meat may originate from the feces and skin of animals presented for slaughter and can be transferred to the carcass during skin removal and evisceration $[2,3]$.

Escherichia coli is a normal commensal microflora of the intestinal tract of animals and humans. In contrast, $E$. coli O157: H7, which is considered as a subtype of Shiga toxinproducing E. coli (STEC) strain, is known to cause human diseases as food borne pathogen and is determined by production of these virulence factors $[3,4]$. The bacterium is known to cause the human illness such as haemorrhagic 
colitis (HC), haemolytic uremic syndrome (HUS), and thrombotic thrombocytopenic purpura (TTP) in all age groups, while children and elderly are more victims [5]. Intimin is responsible for the bacteria's intimate adhesion to intestinal cells, causing the appearance of attachment lesions and erasure of the microvilli of the brush border of enterocytes. Intimin is encoded by the eaeA virulence gene [6]. Furthermore, the organism produces shiga toxin types1 and 2 (stx 1 and stx2) which are responsible for the death of intestinal, vascular, renal cells. They are encoded respectively, by the virulence genes $s t x 1$ and $s t x 2$.

Cattle have been identified as a major reservoir of the organism and shed the bacteria in feces. The role of small ruminants as source of human infection through fecal shedding is being reported in a number of studies. So far, the majority of food poisoning outbreaks were traced to beef contaminated with E. coli $\mathrm{O} 157: \mathrm{H} 7$ [7, 8]. In this regard, the most common route of transmission has been reported to be raw or undercooked minced beef [7]. Nevertheless, varieties of other foods have also been implicated in causing outbreaks [9].

Outbreaks of E. coli $\mathrm{O} 157$ caused infections have been reported in different African countries, stretching from South to east and West parts of the continent [9-11]. However, there is limited data on the prevalence of the organism and its virulence gene diversity in ruminants, especially sheep and goats, and foods of animal origin in Ethiopia [12, 13].

Antibiotic use in STEC infections is controversial because of the potential to increase production and secretion of Shiga toxins [14]. However, increase in antibiotic resistance has been noted over the last 20 years [15-17].

The rising incidence and the potentially serious nature of E. coli 0157 infection are a cause for concern to public health authorities. In line with this, use of sensitive methods to detect $E$. coli $\mathrm{O} 157$ during investigations of outbreaks, surveillance and quality control are recommended [18].

In the presence of the above situations, very few attempts have been made to identify E. coli O157: $\mathrm{H} 7$ under Ethiopian conditions [12, 13]. Therefore, there is paucity of information regarding the prevalence, distribution, virulence characteristics and antibiotic resistance profile of $E$. coli O157: H7 in meat and abattoir house environments in Ethiopia. It has not yet been determined to what extent these environments serve as sources of E. coli O157: H7 particularly to red meat contamination. A study of such types would provide valuable information as to the major sites of contamination in abattoir environments and help in the implementation of strategies to minimize contamination levels.

\section{Materials and methods}

\section{Study area}

Lottery system was used to select the one in Modjo city from six (6) export abattoirs in the country for this study. The study was conducted from November 2012 to April 2013 at the export abattoir in Modjo town, Ethiopia. Modjo is the center of Lume District, eastern Showa administrative zone of Oromia Regional State, 73 $\mathrm{km}$ away from Addis Ababa, at an altitude of $1777 \mathrm{~m}$ above sea level. The average minimum and maximum temperature are $18^{\circ} \mathrm{C}$ and $28^{\circ} \mathrm{C}$ respectively [19].

Although there is seasonal variation, the abattoir slaughters 500-1500 goats every day and 200-600 sheep twice per week. The export abattoir where the study was conducted is well equipped with modern facilities and it is certified of International Organization for Standardization (ISO) 22,000. As an export standard abattoir, there is implementation of HACCP practices for maintaining hygienic standards of the abattoir. Sheep and goat are slaughtered separately but by the same personnel using 'Halal' methods. All slaughtering operations are performed on overhead rails. The skins are washed by tap water; carcasses are washed by pressurized water, trimmed and stored in chilling room till transported to consumers. In the abattoir, there are clean areas for bleeding, dressing, evisceration and meat inspection. Animals slaughtered in the abattoir are exported to Middle East.

\section{Study animals}

The study was conducted on apparently healthy male sheep and goats slaughtered in the export abattoir during the study period. Animals are originated from different parts of the country mainly from Geanear (Bale), Somali, Awash-Metehara, Jima, Ambo, Borena, Arbaminch and Bati (Wollo). Most of them were transported to the abattoir by open aired vehicles, and this study considers these animals starting from the lairage (Fig. 1).

\section{Study design}

A survey was conducted to determine the prevalence of E. coli $\mathrm{O} 157: \mathrm{H} 7$ on skin, feces, intestinal mucosal swab and carcasses of slaughtered animals and abattoir environment (carcass in contacts) particularly knives, water, hook and worker's hand. Swab samples were collected from November 2012 to April 2013.

Systematic random sampling was used to select the sampled animals. Fecal samples and skin, carcass and intestinal mucosal swab samples were collected from each selected animal following their rail (tag) along the line of operation. Swab from abattoir environment, which are in contact with the carcass, were sampled once on each sampling day. Knives, hook, workers hands and the tap water were considered to be carcass in contacts. Water, which was used to wash the carcass, was sampled directly from the tap.

All samples were transported in icebox to Microbiology laboratory, College of Veterinary Medicine and Agriculture, Addis Ababa University (CVMA, AAU) and stored 
at $4{ }^{\circ} \mathrm{C}$ until processed. All samples were processed in $12 \mathrm{~h}$ interval. Culturing, isolation, identification and PCR were performed to determine the presence of E. coli O157:H7 in each sample and most effective drugs against the bacteria were selected after antibiotic sensitivity testing.

\section{Sample size determination}

The number of study animals was determined based on the expected prevalence of E. coli $\mathrm{O} 157: \mathrm{H} 7$ and the desired absolute precision according to the formula stated on Thrusfield [20];

$$
\mathrm{n}=1.96^{2} \mathrm{P}_{\exp }\left(1-\mathrm{P}_{\exp }\right) / \mathrm{d}^{2}
$$

Where:- $\mathrm{n}=$ required sample size; $\mathrm{P}_{\exp }=$ Expected prevalence; $\mathrm{d}=$ desired absolute precision.
Based on a previous study done in Modjo and Debrezeit export and municipal abattoirs, the prevalence rates of $E$. coli $\mathrm{O} 157: \mathrm{H} 7$ in goat and sheep were 2 and $2.5 \%$, respectively [12]. Using these two expected prevalence, 95\% confidence interval and 5\% absolute precision; the number of sampled goats and sheep were estimated to be 31 and 38, respectively.

\section{Sample collection}

Skin swab samples were taken according to McEvoy et al. [20], by using $2 \times 3 \mathrm{~cm}$ sterile cotton tipped swabs soaked in approximately $10 \mathrm{ml}$ of buffered peptone water (Oxoid Ltd., Hampshire, England). Skins were swabbed from the neck of animals over the line of bleeding before slaughtering near the bleeding area at an area of approximately $10 \times 10 \mathrm{~cm}$. Skin of the ventral midline part

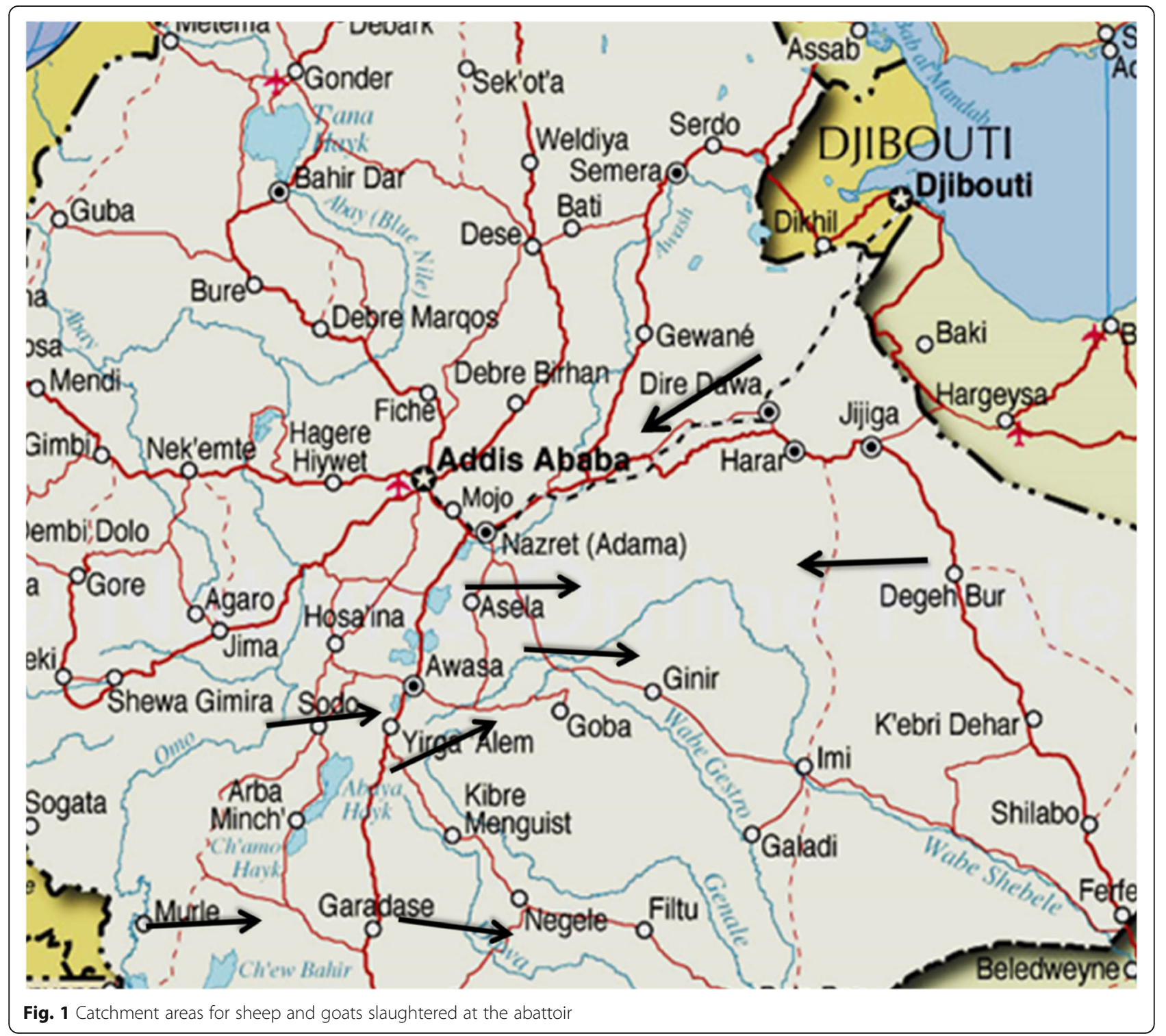


of the animal was also swabbed similarly at the mid line to determine its contact to the carcass during flaying (Fig. 2). The shaft of the swab was then broken by pressing it against the inner wall of the test tube and disposed. Finally this was repeated but with a dry sterile cotton.

Approximately $25 \mathrm{~g}$ of fecal samples were taken after complete evisceration directly by opening the rectum according to the method described by Elder et al. [21].
The whole abdominal digestive organs were separated from the slaughtering line in a plastic bucket and the rectum was opened using a sterile surgical blade (Fig. 2); the fecal sample was then put in to sterile universal bottle. Whereas for intestinal mucosal swab sampling, the distal colon was ligated and opened using a sterile surgical blade proximal to the rectum and the lumen was swabbed by using sterile swab. The swab was then introduced in to

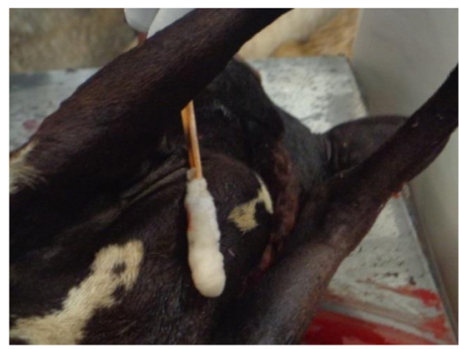

A

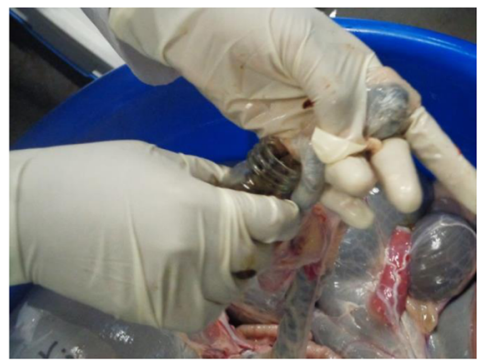

$\mathrm{C}$

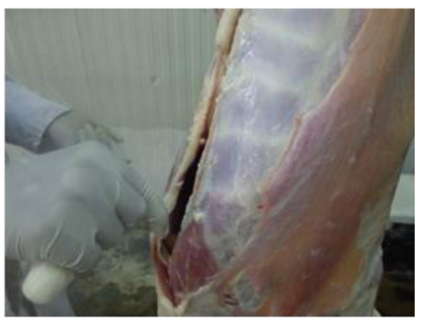

$\mathrm{E}$

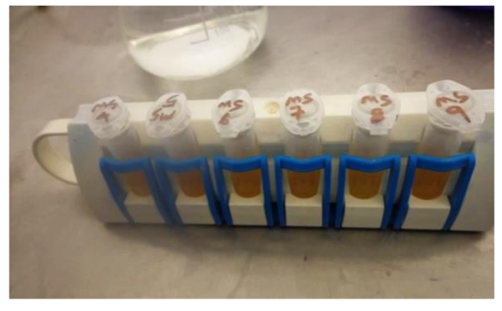

F

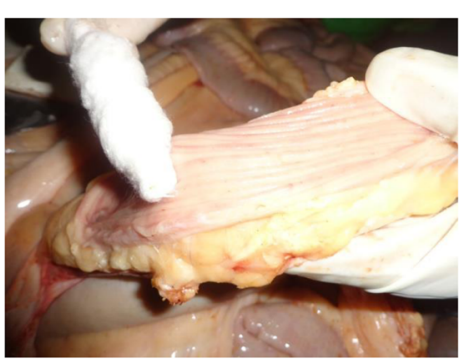

B

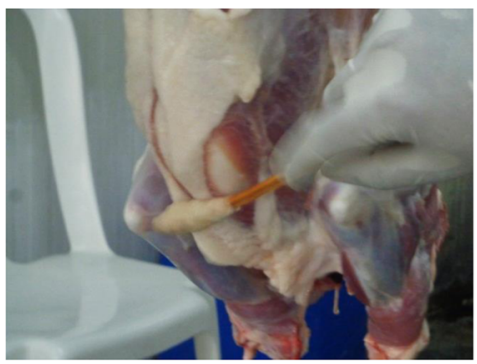

$\mathrm{D}$

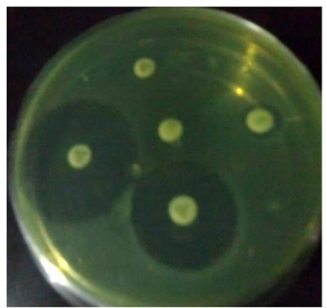

G

Fig. 2 Procedures followed during sample collection and processing: a skin swab sample collection; b intestinal mucosal swab sample collection; c fecal sample collection; $\mathbf{d}$ carcass outside swab sample collection; e carcass inside swab sample collection; $\mathbf{f}$ concentration of E. coli O157:H7 using IMS technique; $\mathbf{g}$ antimicrobial susceptibility test bacterial isolates 
approximately $10 \mathrm{ml}$ buffered peptone water in a sterile test tube.

The external parts of carcasses were swabbed from rump, midline and brisket area, just before chilling according to the methods described by McEvoy et al. [22]. Sterile cotton swabs soaked in approx. $10 \mathrm{ml}$ of buffered peptone water was used to rub against the carcass first horizontally then vertically. A second dry sterile cotton swab was also rubbed at exactly the same area. For the internal part of the carcass, where contacts with other carcass is not possible, the thoracic and the pelvic parts of both sides, through the evisceration opening, were swabbed using the same procedure as above (Fig. 2). Disposable sterile gloves were used for each carcass and changed.

Similarly, abattoir utensils and other carcass in contacts such as knife, hook, water and workers hands were also swabbed as a sample using sterile cotton swabs soaked in approx. $10 \mathrm{ml}$ of buffered peptone water. A pooled sample was taken from knives used for evisceration and carcass trimming on each sampling day. Only hooks used to hang the sampled carcass were also swabbed each sampling day as a pooled sample. Whereas abattoir workers whose hands have direct access to the washed carcass were swabbed for sampling, at their palm surface and fingers. Hand washing is practiced almost regularly. They wash their hands between each work which was practiced according to the abattoirs particular HACCP procedures. Moreover, $25 \mathrm{ml}$ of water sample was collected directly from the tap which is used for washing of the carcass.

For each and every sampling a sterile latex glove was used to avoid cross contamination and every procedure was done as aseptic as possible. All samples were transported in ice box to the laboratory.

\section{Laboratory work}

\section{Bacteriological sample processing}

Fecal samples were measured for accuracy and placed in to sterile stomacher bag and a 1:9 ratio of a modified tryptone soya broth (Oxoid Ltd., Hampshire, England) containing $20 \mathrm{mg} \mid \mathrm{l}$ novobiocin (Sigma, Steinheim, Germany) $(\mathrm{mTSB}+\mathrm{n})$ was added in it, and agitated in stomacher (Seward Stomacher 400, Seward, London, UK) for agitation at low speed for $30 \mathrm{~s}$.

In to all other swab samples $90 \mathrm{ml}$ of $\mathrm{mTSB}+\mathrm{n}$ was added and homogenized using vortex mixer, and also for the $25 \mathrm{ml}$ water sample $225 \mathrm{ml} \mathrm{mTSB}+\mathrm{n}$ was added just to keep the 1:9 ratio.

\section{Isolation and identification of E. coli 0157:H7}

Microbiological samples for the isolation and identification of this bacterium were processed as described as follows.
Selective enrichment Modified tryptone soya broth containing $20 \mathrm{mg} / \mathrm{l}$ novobiocin (Oxoid, Ltd., Hampshire, England) was used at 1:9 ratios as mentioned above, for selective enrichment of all the samples. Then, all the samples types were incubated at $41.5^{\circ} \mathrm{C}$ for $24 \mathrm{~h}$.

Isolation by immuno magnetic separation (IMS) and culturing of the isolates After $24 \mathrm{~h}$ of incubation all enriched broth culture were processed using IMS using Dynabeads anti-E. coli O157 (Dynal Biotech AS, ThermoFisher Scientific, Oslo, Norway) as follows. Both enriched broth culture and the paramagnetic beads were homogenized by vortexing and $1 \mathrm{ml}$ of the enriched culture was put in to a sterile screw cupped eppendrof tube. A $20 \mu \mathrm{l}$ of resuspended paramagnetic beads (Dynal Biotech AS, ThermoFisher Scientific, Oslo, Norway) was then transferred in to the same eppendrof tube, which was briefly vortexed on the dynal mixer (Dynal MX4sample mixer) (Dynal Biotech AS, ThermoFisher Scientific, Oslo, Norway) at $20 \mathrm{rpm}$ for $30 \mathrm{~min}$ at room temperature, for the bacteria to attach to antibody surface on the beads. The tubes were then put in to the manual magnetic particle concentrator (MPC-S) (Dynal Biotech AS, ThermoFisher Scientific, Oslo, Norway) with the magnetic strip in place, inverted 3 to 4 times and left to settle for about $5 \mathrm{~min}$. It was then gently rotated for the magnetic beads to concentrate at the back of the tube. The cap of the tube carefully opened and the supernatant was discarded by carefully aspirating it with sterile fine tipped pipette, without touching the back wall of the tube. Then magnetic strip was removed and $1 \mathrm{ml}$ of phosphate buffered saline containing 0.05\% tween 20 (PBST, Sigma chemicals Co, Saint Louis, USA) was added to each tube using another disposable fine tipped pipette. It was then inverted 3 times after the tubes were clothed, the magnetic strip replaced and the above step repeated at least twice. To prevent cross contamination the PBST was put in different small containers and for each sample and each material transferring new pipette tips were used. Finally the supernatant was aspirated; the magnetic strip was removed and about $100 \mu \mathrm{l}$ of PBST was added in each tube and mixed gently [23].

Around $50 \mu \mathrm{l}$ of IMS bead and bacteria complex were streaked onto Sorbitol MacConkey agar (Difco, Becton Dickinson, Claix, France) containing $0.05 \mathrm{mg} / \mathrm{l}$ cefixime and $2.5 \mathrm{mg} / 1$ potassium tellurite (Dynal Biotech ASA, Oslo, Norway) (CT-SMAC). Culturing was carried out carefully to obtain pure colonies and plates were incubated at $37^{\circ} \mathrm{C}$ for $20-24 \mathrm{~h}$. The CT-SMAC agar plates were examined for the presence of non-sorbitol fermenting colonies [24-27].

The non-sorbitol fermenting colonies on CT-SMAC appear as slightly transparent, almost colorless with a 
weak pale brownish appearance with a diameter of 1 mm $[24,25,27]$. Such colonies are sub cultured on CTSMAC for further a confirmatory test.

Confirmatory test by latex agglutination.

Latex agglutination was performed for confirmation of E. coli O157:H7 using latex kit (ThermoFisher Scientific, Oslo, Norway). The latex kit consists of four components: latex test reagent, latex control reagent, the positive controls and negative controls. The test reagent is latex particles sensitized with specific rabbit antibody against $\mathrm{O} 157$ antigen and the control reagent consists of latex particles sensitized with rabbit globulin. The positive and negative controls are suspension of inactivated E. coli $\mathrm{O} 157: \mathrm{H} 7$ cells and inactivated non-specific E. coli cells respectively.

The test was performed according to the manufacturer instructions (Oxoid Ltd., Hampshire, England). But first the latex kit was checked for its performance by using the control suspensions in the kit, the test was continued after the positive control reacts with the test latex showing positive result. A drop of test latex and $0.085 \%$ sterile saline water were dispensed in to the reaction card separately. A few presumptive colonies (an average of 2 colonies) of $E$. coli $\mathrm{O} 157$ were taken and emulsified in to the saline water on the latex card, then slowly mixed with the test latex and checked for agglutination within $1 \mathrm{~min}$. Isolates showing visible agglutination by reacting with the test latex solution are again sub cultured for virulent gene identification.

\section{Determination of virulence genes by polymerase chain reaction}

Multiplex PCR was conducted to assess the presence of virulence genes (stx1, stx2 and eaeA) in E. coli O157:H7 colonies, which were confirmed by latex agglutination, by using the methods described in Mora et al. [16] and Inat and Siriken [28]. DNA was extracted by boiling the isolates. Thus, each suspect colony was inoculated on CT-SMAC and incubated for $24 \mathrm{~h}$ at $37^{\circ} \mathrm{C}$ to get fresh colony. Few colonies were then selected and suspended separately in $100 \mu \mathrm{l}$ of sterile distilled water in eppendorf tubes; the suspensions were then boiled at $92.5^{\circ} \mathrm{C}$ for 17 $\mathrm{min}$ in a water bath. After centrifuging at $13000 \mathrm{rpm}$ for $10 \mathrm{~min}$, the supernatant containing the template DNA was transferred into nuclease-free eppendorf tubes, and were stored at $-20^{\circ} \mathrm{C}$ until use.
Detection of the stx1, stx 2 and eaeA genes was performed according to the protocol indicated in Inat and Siriken [28] with slight modification. Thus, $2 \mu \mathrm{l}$ of extracted DNA was used as a template in a reaction mixture with a final volume of $25 \mu \mathrm{l}$ that contained $10 \mathrm{mM}$ of each dNTP, $25 \mathrm{nM} s t x 1$ primer, $25 \mathrm{nM}$ stx 2 primers, $25 \mathrm{nM}$ eaeA primer (Table 1), $1 \mathrm{U}$ of Taq DNA polymerase (Qiagen, Hilden, Germany) in $1 \times$ PCR buffer and 2 $\mathrm{mM}$ of $\mathrm{MgCl}$. Amplification of DNA was conducted using initial denaturation at $95^{\circ} \mathrm{C}$ for $3 \mathrm{~min}, 35$ cycles of denaturation at $95^{\circ} \mathrm{C}$ for $20 \mathrm{~s}$, annealing at $58^{\circ} \mathrm{C}$ for 40 s, extension at $72{ }^{\circ} \mathrm{C}$ for $1 \mathrm{~min}$, and final extension at $72{ }^{\circ} \mathrm{C}$ for $8 \mathrm{~min}$.

For gel electrophoresis, the 10- $\mu$ l amplicon mixture was loaded onto a $1.5 \%$ agarose gel. Electrophoresis was conducted at $125 \mathrm{~V}$ for $1 \mathrm{~h}$. A 100 up to $1000 \mathrm{bp}$ molecular weight marker was used to identify the amplified products as a ladder, which was visualized by UV illumination.

\section{Antimicrobial susceptibility pattern}

Antimicrobial susceptibility testing was performed following the standard agar disk diffusion method according to CSLI [30] using commercial antimicrobial disks (Oxoid Ltd., Hants, UK). The selected antimicrobials their symbols and inhibition zone size interpretations are listed in Table 2.

Pure colonies, incubated for $6 \mathrm{~h}$ in Tryptone Soya Broth (Oxoid Ltd., Hants, UK) were processed to a turbidity of 0.5 McFarland standards (approximately $3 \times 10^{8}$ CFU per $\mathrm{ml}$ ) in a sterile saline solution. Then, they were inoculated on Muller-Hinton agar plates (Becton Dickinson company, Cockeysville USA) using sterile cotton swab, making sure that all the surface of the media is immersed with the bacterial suspension. Antibiotic discs (Oxoid Ltd., Hants, UK) were then dispensed and plates were incubated for $24 \mathrm{~h}$ at $37^{\circ} \mathrm{c}$. Diameters of the zone of inhibition were measured and the results were classified as resistant, intermediate and susceptible according to CLIS [30]. E. coli ATCC 25922 type strains were used as a positive control.

\section{Data collection, management and analysis}

The establishment of computer database and the necessary manipulations such as variable coding was performed using MS Excel (Microsoft ${ }^{\circ}$ Excel $^{\circ}$ 2010, Microsoft Corporation; Santa Rosa, California, USA). The database was

Table 1 Primers' sequence used in multiplex PCR for amplification of st 1 , st $\times 2$ and eaeA genes

\begin{tabular}{llll}
\hline Target gene & Primers sequence $\left(5^{\prime}\right.$-3') (Forward/reverse) & Amplicon size (bp) & Reference \\
\hline st $x 1$ & ATAAATCGCCATTCGTTGACTAC/ AGAACGCCCACTGAGATCATC & 180 & [27] \\
stx2 & GGCACTGTCTGAAACTGCTCC/ TCGCCAGTATCTGACATTCTG & 255 & [27] \\
eaeA & GACCCGGCACAAGCATAAGC/ CCACCTGCAGCAACAAGAGG & 384 & [29] \\
\hline
\end{tabular}


Table 2 Antimicrobials used, their symbols and inhibition zone size interpretation for Gram-negative enteric bacteria

\begin{tabular}{|c|c|c|c|c|c|}
\hline \multirow[t]{2}{*}{ Antimicrobial used $^{a}$} & \multirow[t]{2}{*}{ Symbols } & \multicolumn{4}{|c|}{ Diameter of zone of inhibition in mill meter } \\
\hline & & Resistant $\leq$ & Intermediate & Moderately Susceptible & Susceptible $\geq$ \\
\hline Amoxicillin $(25 \mu \mathrm{g})$ & AML & 13 & - & $14-16$ & 17 \\
\hline Bacitracin $(10 \mu \mathrm{g})$ & B & 14 & $15-16$ & - & 17 \\
\hline Cefotaxime $(5 \mu \mathrm{g})$ & CTX & 14 & - & $15-22$ & 23 \\
\hline Cefoxitin $(30 \mu \mathrm{g})$ & FOX & 14 & - & $15-17$ & 18 \\
\hline Ceftazidime $(10 \mu \mathrm{g})$ & CAZ & 12 & $13-17$ & - & 18 \\
\hline Cefuroxime Sodium(5 $\mu \mathrm{g})$ & CXM & 14 & - & $15-22$ & 23 \\
\hline Clindamycine $(10 \mu \mathrm{g})$ & DA & 14 & $15-20$ & - & 21 \\
\hline Cloxacillin $(5 \mu \mathrm{g})$ & $\mathrm{OB}$ & 13 & - & $14-16$ & 17 \\
\hline Doxycycline $(30 \mu \mathrm{g})$ & DO & 13 & - & $14-16$ & 17 \\
\hline Kanamycin $(30 \mu \mathrm{g})$ & K & 13 & $14-17$ & - & 1 \\
\hline Nalidixic acid (30 $\mu \mathrm{g})$ & NAL & 13 & $14-18$ & - & 19 \\
\hline Nitrofurantoin $(300 \mu \mathrm{g})$ & $\mathrm{F}$ & 13 & $14-17$ & - & 18 \\
\hline Norfloxacin $(10 \mu \mathrm{g})$ & NOR & 12 & $13-16$ & - & 17 \\
\hline Polymyxin B (300 unit) & $\mathrm{Pb}$ & 8 & $9-11$ & - & 12 \\
\hline Vancomycin $(30 \mu \mathrm{g})$ & VA & 14 & $15-16$ & - & 17 \\
\hline
\end{tabular}

all are Oxoid products (England)

transferred to SPSS version 11.5 (IBM Corporation, New York, USA) [31] for analysis. Descriptive statistics such as proportions, standard deviations and 95\% confidence intervals were performed. Over all and sample-specific prevalence were determined by dividing the number of positive samples to the total number of samples examined. Difference among and between proportions of the groups with certain determinant factors was determined by chisquare $\left(\mathbf{X}^{\mathbf{2}}\right)$ test. ORs were calculated using univariable logistic regression to determine the degree of associations of carcass contamination with fecal, skin and carcass in contact surfaces' status. A $p$-value $<0.05$ was considered indicative of a statistical significance difference.

Furthermore, Kappa statistics was performed to see whether there is agreement between fecal sample and intestinal mucosal as well as carcass inside and carcass outside swab E. coli O157: H7 status. Interpretation of the Kappa test was based on Rules-of-thumb for kappa: values less than 0.40 indicate low association; values between 0.40 and 0.75 indicate medium association; and values greater than 0.75 indicate high association between the two raters.

\section{Results}

This study was conducted on 40 and 32 apparently healthy slaughtered sheep and goats, respectively, at an export abattoir, Modjo, Ethiopia, from November 2012 to April 2013. Bacteriological examination was conducted on fecal, skin, intestinal mucosal, carcass outside and carcass inside swab samples, and swabs from knife, personnel's hand and hook as well as water samples. Carcass in contact samples were 12 each, since they were taken as a pool sample at each sampling day. Whereas, the other specific samples were taken from each animal, so were 72 each.

\section{Prevalence of E. coli 0157:H7}

From 408 samples examined for E. coli O157:H7 only 20 (4.9\%) were found to be positive. It was present in feces, intestinal mucosal swabs, skins, inside and outside carcass swabs and knife used in the abattoir. From these 20 positive samples $70 \%(14 / 20)$ were from sheep and $25 \%(5 / 20)$ were from goats, the rest $5 \%(1 / 20)$ was from a knife.

Statistically significant difference $(p<0.05)$ was found in prevalence of $E$. coli $\mathrm{O} 157: \mathrm{H} 7$ between sheep and goats (Table 3). Due to low prevalence, small sample size and the abattoirs use of the same line for both species, complete separation of ovine and caprine for analysis was difficult. An animal was considered E. coli O157: H7 positive when it was positive for the bacteria on either fecal sample and/or intestinal mucosal swab; samples from fecal or intestinal mucosal swabs of goats were not positive. Skin, carcass inside, and carcass outside E. coli O157: H7 statuses were considered indicators of external contamination and were not used for the calculation of prevalence on animals. As a result, from the total 72 animals examined for the status of $E$. coli O157: H7, only 8 animals are considered positive. Statistically significant difference was observed between sheep and goat in harboring the bacteria; sheep being more prone to harbor E. coli $\mathrm{O} 157: \mathrm{H} 7$ than goats. 
Of the 8 positive animals, only $2(25 \%)$ were culture positive both for fecal sample and intestinal mucosal swab samples. The rest $6(75 \%)$ were culture positive either for fecal sample or intestinal mucosal swab sample and were significantly different $(P=0.033)$. The agreement of the fecal sample and intestinal mucosal swab samples was measured using the Kappa statistics and the result indicated low agreement between the two (Kappa value $=0.357,95 \% \mathrm{CI}=0.002-3.103)$ (Table 4).

From all randomly selected 72 animals each type of samples were taken. Of the different sample types taken four fecal (5.55\%), five skin swab (6.94\%), six intestinal mucosal swabs $(8.33 \%)$, one carcass inside swab (1.39\%) and three carcass outside swab (4.17\%) samples were found to be positive (Table 3). However, all the swab samples from personnel's hand and hook as well as water samples were found to be negative for $E$. coli O157: H7.

The internal part of the carcass was also sampled to determine the impact of carcass contamination by feces especially during evisceration. It was thought to be helpful in avoiding the risk of contamination of the carcass by other in contacts, like washing water, hand etc. and evaluate only the risk of carcass contamination by feces during evisceration. Contamination of the inside part of the carcass will be from evisceration problems rather than external contacts and cross contaminations. If there were evisceration problems like opening the gut accidentally or others, it was believed that, contaminations will be at the midline and bottom part of the visceral part on the carcass. However, of all 72 samples of carcass inside samples taken during this study only $1(1.39 \%)$ was found to be positive for $E$. coli $\mathrm{O} 157: \mathrm{H} 7$ from sheep, with no significant importance.

The level of carcass outside contamination was considered as an outcome variable taking skin swab, fecal sample and knife swab as risk factors for carcass contamination. However, assessments using logistic regression analysis as well as Chi square test did not show significant associations between carcass contamination and the risk factors were (Table 5).
Table 4 Comparative results by Pearson's $X^{2}$ test of speciesspecific E. coli O157: H7 prevalence in fecal sample and intestinal mucosal swabs

\begin{tabular}{llll}
\hline Sample type & $p$-value & Odds Ratio & Cl for the Odds Ratio \\
\hline Fecal & 0.124 & 1.111 & $1.002-1.232$ \\
Mucosal swab & 0.030 & 1.176 & $1.033-1.340$ \\
\hline
\end{tabular}

Even if there is no association with carcass contamination in our finding, a higher prevalence of E. coli O157: H7 from skin swabs (6.94\%) than from fecal samples of sheep $(8.33 \%)$ was observed.

In the abattoir where these samples were collected, cold pressurized water wash was used to avoid visible contaminants such as blood clot, fecal debris, GIT (Gastro Intestinal Tract) contents so on. This was done after evisceration and inspection. The whole carcass surface was washed with this pressure wash. In addition to this, carcass trimming was performed using knives immersed in hot water after trimming of every carcass. The water was boiled at $100{ }^{\circ} \mathrm{C}$, and used on open air, until changed with another batch of water. Carcasses are transferred manually by carrying from the overhead rails to the chilling room after weighing.

In addition, no positive carcasses were found from animals that were E. coli $\mathrm{O} 157: \mathrm{H} 7$ negative from their fecal, mucosal swab or skin samples.

Similarly, the level of carcass inside contamination was considered as an outcome variable taking skin swab, fecal sample and knife swab as risk factors for carcass contamination. However, such contamination sources were not significantly associated with carcass contamination and E. coli $\mathrm{O}$ 157: $\mathrm{H} 7$ status of the risk factors (Table 6).

\section{Detection of virulence genes on the isolates}

From the 20 E. coli $\mathrm{O} 157: \mathrm{H} 7$ isolates that were analyzed by PCR for the detection of virulence genes, 10 (50\%) were found to be positive for having virulent genes. Among these 10 isolates, $7 / 20$ (35\%) of them are found to carry both eaeA and stx 2 and $3 / 20$ (15\%) carried only

Table 3 Prevalence of E. coli O157: H7 by sample types and species of animals examined

\begin{tabular}{|c|c|c|c|c|c|c|c|c|c|}
\hline \multirow[t]{3}{*}{ Sample Type } & \multicolumn{9}{|c|}{ Number of samples } \\
\hline & \multicolumn{3}{|l|}{ Goats } & \multicolumn{3}{|l|}{ Sheep } & \multicolumn{3}{|l|}{ Total } \\
\hline & Examined & Positives (\%) & $95 \% \mathrm{Cl}$ & Examined & Positives (\%) & $95 \% \mathrm{Cl}$ & Examined & Positives (\%) & $95 \% \mathrm{Cl}$ \\
\hline Fecal & 32 & $0(0)$ & $0-0$ & 40 & $4(10.0)$ & $-0.39-20.39$ & 72 & $4(5.6)$ & $2.9-10.91$ \\
\hline Skin Swab & 32 & $3(9.4)$ & $-0.71-19.51$ & 40 & $2(5.0)$ & $-2.55-12.55$ & 72 & $5(6.9)$ & $1.05-12.75$ \\
\hline Mucosal Swab & 32 & $0(0)$ & $0-0$ & 40 & $6(15.0)$ & $2.63-27.37$ & 72 & $6(8.3)$ & $1.93-14.67$ \\
\hline Carcass outside & 32 & $2(6.2)$ & $-2.16-14.56$ & 40 & $1(2.5)$ & $-2.91-7.91$ & 72 & $3(4.2)$ & $-0.43-8.83$ \\
\hline Carcass inside & 32 & $0(0)$ & $0-0$ & 40 & $1(2.5)$ & $-2.91-7.91$ & 72 & $1(1.4)$ & $-1.31-4.11$ \\
\hline Knife & & & & & & & 12 & $1(4.2)$ & $-0.43-8.83$ \\
\hline
\end{tabular}

Cl Confidence interval 
Table 5 Association of carcass outside contamination and E. coli 0157: H7 status of the risk factors

\begin{tabular}{llll}
\hline Risk factors & $p$-value & Odds Ratio & $\begin{array}{l}95 \% \text { Confidence } \\
\text { interval for the } \\
\text { Odds Ratio }\end{array}$ \\
\hline Skin swab & 0.999 & 0.928 & $0.868-0.991$ \\
Fecal sample & 0.999 & 0.942 & $0.888-0.999$ \\
Knife swab & 1.000 & 0.986 & $0.958-1.014$ \\
\hline
\end{tabular}

the eaeA genes; whereas no one of them carried the $s t x 1$ gene (Table 7).

Out of the six isolates of the intestinal mucosal swabs of sheep four $(66.7 \%)$ of them express the virulence genes, but only one of the four fecal isolates (25\%) has these genes as a virulent factor. This shows the significance of $e a e A$ being more prevalent in mucosal isolates than faecal isolates in this study. Of the caprine isolates both the carcass outside isolates show eaeA genes, but only one of them are with the $s t x 2$, whereas from the three isolates of skin swabs, two of them show eaeA and only one was with stx2. The only one carcass in contact isolate, from Knife was also found to express the eae $A$ virulent gene.

In our finding seven of the isolates from goat and sheep had both eaeA and stx 2 genes and three of them were with only the eaeA gene (Table 7, Fig. 3), but none of them show the $s t x 1$ gene.

\section{Antimicrobial susceptibility of the isolates}

Testing of all the $20 \mathrm{E}$. coli O157: $\mathrm{H} 7$ isolates for fifteen different antimicrobials showed susceptibility to one of the antimicrobial used, Norfloxacin (NOR) (100\%). However, another two antibiotics show growth inhibition zones for all isolates, even if two of the isolates (10\%) are moderately susceptible for Ceftazidime (CAZ) and another completely different two isolates (10\%) showed intermediate resistance to polymixin-B (PB). Another antibiotic showed growth inhibition zones on four of the isolates $(20 \%)$ was Kanamycin (K), even if it was not enough to consider it as an effective drug (Table 8).

Table 6 Association of carcass inside contamination and E. coli O 157: H7 status of the risk factors

\begin{tabular}{llll}
\hline Risk factors & $p$-value & Odds Ratio & $\begin{array}{l}95 \% \text { Confidence } \\
\text { interval for the } \\
\text { Odds Ratio }\end{array}$ \\
\hline Fecal sample & 0.999 & 0.944 & $0.892-0.999$ \\
Knife swab & 1.000 & 0.986 & $0.959-1.014$ \\
\hline
\end{tabular}

\section{Discussion}

Carcass contamination with E. coli $\mathrm{O} 157: \mathrm{H} 7$ may occur during slaughtering operations because of direct contact with contaminated materials such as skin, fecal material, knives, workers' hands and the likes $[2,3]$.

\section{Prevalence of E. coli 0157:H7}

While cattle are generally regarded as the main reservoir of $E$. coli $\mathrm{O} 157: \mathrm{H} 7$ for human infection on other studies [8], the results of the present study indicate that sheep and goats may also be contributing sources, with sheep being more significant. This finding is in line with several previous studies which have indicated sheep as a reservoir of this bacteria $[8,32-35]$. Nevertheless, it is not in agreement with a previous study in another export abattoir in Modjo, Ethiopia, which showed that both species are equally potential important sources of human E. coli O157:H7 infections [13]. This is may be due to the lack of the previous study to consider intestinal mucosal swab as a sample, since it shows the highest number of isolates in this study.

A $10 \%$ fecal prevalence of $E$. coli $\mathrm{O} 157: \mathrm{H} 7$ from sheep in this study was a little higher than previous studies conducted in this country and in other countries. Mersha et al. [13] reported a relatively lower (5.4\%) prevalence of E. coli O157:H7 in sheep feces in the country. Similar low levels were reported in Netherlands [18], $4 \%$ in ewes and $4 \%$ in lambs, in Spain [32], 3\% in lambs, in UK [6, 35], 1.7\% in sheep in Great Britain [36], 1.4\% in sheep, and in Italy [8], 0.2\%. However, a much higher prevalence of $18 \%$ in Turkey [37], 31\% in USA [38] and 68\% from sheep flocks in Australia [39] from fecal samples were reported. On the other hand, zero E. coli O157:H7 prevalence from sheep fecal samples were reported in Norway [40], Scotland [41], Ireland [35], Greece [42] and United States [43]. Similarly, this study have smaller bacterial findings but on caprine. Closer results, however, are reported in Greece (1 out of 81 ) associated with human outbreaks from goats [42]. Similarly, Keen et al. [43] reported no E. coli O157:H7 from 526 goats' in US zoological parks. In contrast, higher prevalence observed in other countries. A prevalence ranging from 55 to $95 \%$ reported in France [44] and 40\% in Australia [45] in goats by flocks.

Marked differences in the prevalence of E. coli O157: H7 from fecal samples were observed in both sheep and goats. The variations in prevalence among the various studies could be due to different reasons such as variations animal management systems, geographical and climatic factors, sampling times and sampling technique, animal inherent factors, and so on. A number of studies have also shown that prevalence of $E$. coli O157:H7 shed from animal feces can vary significantly in relation to time, age of animals, nature of feeds etc. [3, 7, 25]. 
Table 7 Summary of virulent gene expression of E. coli O157:H7 isolates

\begin{tabular}{llllll}
\hline Species & Type of sample & & \multicolumn{3}{l}{ Virulent genes expressed } \\
\cline { 5 - 6 } animals & & eaeA & stx1 & stx2 & Both stx2 \& eaeA \\
\hline Sheep & Mucosal swab & 4 & - & 4 & 4 \\
& Fecal sample & 1 & - & 1 & 1 \\
\multirow{4}{*}{ Goat } & Carcass outside & 2 & - & 1 & 1 \\
& Skin swab & 2 & - & 1 & 1 \\
& Knife & 1 & - & - & - \\
& Total & 10 & 0 & 7 & 7 \\
\hline
\end{tabular}

Moreover, Battisti et al. [8] indicated sheep husbandry as a possible reasons for E. coli $\mathrm{O} 157$ fecal prevalence differences in US as compared to European countries. In connection to this, a meta-analysis by Islam et al. [46] showed that world region, type of cattle breed and to some extent, specimens as well as method of pre-enrichment, were identified as factors for variation in the prevalence estimates of the organism in cattle worldwide. On the other hand, super-shedding animals may play unique roles in prevalence differences in various geographical regions as reported by McPherson et al. [47], where supper-shedding is indicated to contribute to contamination of hides in cattle, has also been reported in sheep. This could have an impact of the lower rate of detection of the organism in the current study.

The overall prevalence in skin swabs $(6.9 \%)$ was comparable to the previous study done in export abattoir of Modjo, Ethiopia [13]. Isolation of E. coli O157:H7 from skin of these species is very rarely described. In Ireland as reported by Lenahan et al. [35], a 5.8\% prevalence of
E. coli $\mathrm{O} 157: \mathrm{H} 7$ from fleece, sampled by shaving was reported. However, in hides zero to $22 \%$ E. coli $\mathrm{O} 157: \mathrm{H} 7$ prevalence were reported from different sites of hides in US [3, 22].

E. coli $\mathrm{O} 157: \mathrm{H} 7$ prevalence of $4.17 \%$ from carcass outside swab in the current finding was comparable to a previous study done in east Showa of Ethiopia on meat samples of sheep and goat [12]. Lower prevalence than the present finding was reported in Ireland [35] and in England [7] that ranges between 0.7 and 4\% from goats and sheep carcasses. Similarly, Chapman et al. [7] in UK reported $0.21,1.22$ and $1.17 \%$ prevalence of $E$. coli O157: $\mathrm{H} 7$ from minced meat, burger and sausages of lambs, respectively. On the other hand, much higher prevalence was reported from an export abattoir of Ethiopia by Mersha et al. [13], 8.7\%, and in Australia by SidjabatTambunan and Bensink [42], 29.2\% (31/106) from sheep carcasses.

Differences in the reported prevalence could be due to differences in the method of sampling, number of samples, sampling sites, and so on. Thus, MacEvoy [22] recovered only one among the nine positive samples by swabbing but six by excision, showing sampling methods can be big factor. The surface swabbing method, which was used in this study, however, was also used by others $[13,29]$ and depending on the degree of abrasiveness the method is recommended as an alternative method since it is cost effective and nondestructive.

The internal part of the carcass was also sampled to determine the impact of carcass contamination by feces especially during evisceration. It was thought to be helpful in avoiding the risk of contamination of the carcass by other in contacts, like washing water, hand etc. and evaluate only the risk of carcass contamination by feces

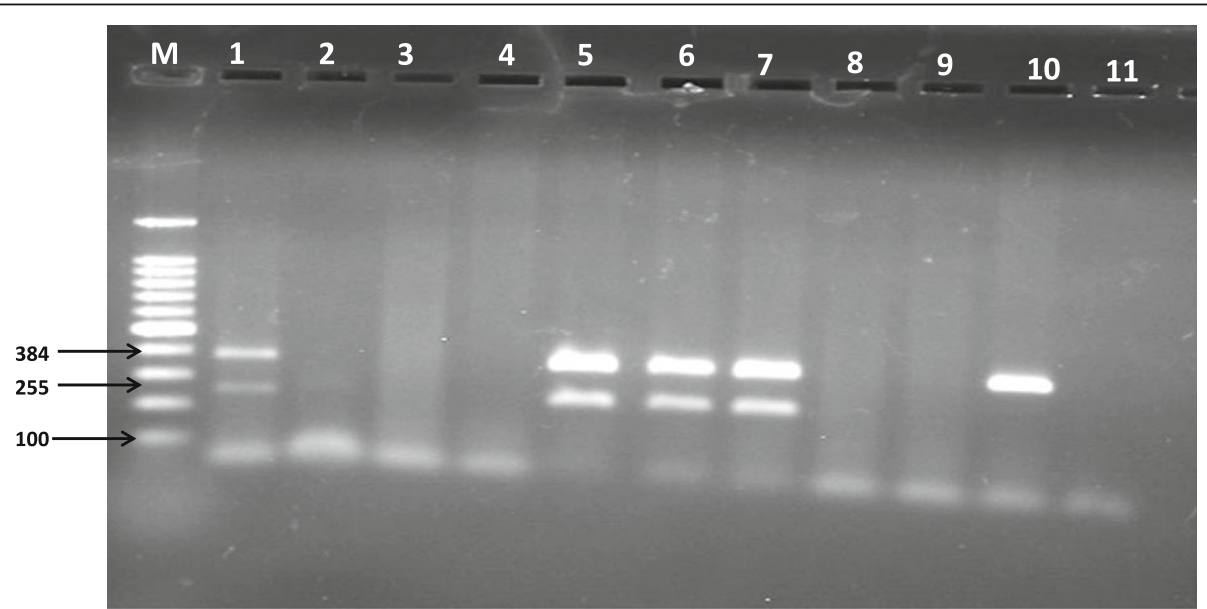

Fig. 3 Amplification products of eaeA and stx2 virulent genes of E. coli O157:H7 isolated from sheep \& goat . M=100 bp DNA marker; 1-10 PCR products, the amplicon sizes of eaeA and stx2 are $384 \mathrm{bp}$ and $266 \mathrm{bp}$, respectively; 11 = Negative contro, (PCR grade water) 
Table 8 Antimicrobial susceptibility pattern of E. coli O157: H7 isolates by species and sample type. N.B: All isolates was resistant to the rest of antibiotics tested in this study

\begin{tabular}{|c|c|c|c|c|c|c|c|c|c|c|c|}
\hline \multirow{3}{*}{$\begin{array}{l}\text { Species } \\
\text { of } \\
\text { animal }\end{array}$} & \multirow{3}{*}{$\begin{array}{l}\text { Type } \\
\text { of } \\
\text { sample }\end{array}$} & \multirow{3}{*}{$\begin{array}{l}\text { No of } \\
\text { isolates } \\
\text { tested }\end{array}$} & \multicolumn{9}{|c|}{ Susceptibility Pattern } \\
\hline & & & \multicolumn{3}{|c|}{ Norfloxacin } & \multicolumn{3}{|l|}{ CAZ } & \multicolumn{3}{|l|}{ PB } \\
\hline & & & $\begin{array}{l}\text { Sen. } \\
\text { No. (\%) }\end{array}$ & $\begin{array}{l}\text { Int. } \\
\text { No. (\%) }\end{array}$ & $\begin{array}{l}\text { Res. } \\
\text { No. (\%) }\end{array}$ & $\begin{array}{l}\text { Sen. } \\
\text { No. (\%) }\end{array}$ & $\begin{array}{l}\text { Int. } \\
\text { No. (\%) }\end{array}$ & $\begin{array}{l}\text { Res. } \\
\text { No. (\%) }\end{array}$ & $\begin{array}{l}\text { Sen. } \\
\text { No. (\%) }\end{array}$ & $\begin{array}{l}\text { Int. } \\
\text { No. (\%) }\end{array}$ & $\begin{array}{l}\text { Res. } \\
\text { No. (\%) }\end{array}$ \\
\hline \multirow[t]{2}{*}{ Goat } & Skin & 3 & 3 & 0 & 0 & 3 & 0 & 0 & 3 & 0 & 0 \\
\hline & $\mathrm{CO}$ & 2 & 2 & 0 & 0 & 2 & 0 & 0 & 2 & 0 & 0 \\
\hline \multirow[t]{6}{*}{ Sheep } & Fecal & 4 & 4 & 0 & 0 & 3 & 1 & 0 & 2 & 1 & 0 \\
\hline & Skin & 2 & 2 & 0 & 0 & 2 & 0 & 0 & 2 & 0 & 0 \\
\hline & MS & 6 & 6 & 0 & 0 & 5 & 1 & 0 & 6 & 0 & 0 \\
\hline & $\mathrm{CO}$ & 1 & 1 & 0 & 0 & 1 & 0 & 0 & 1 & 0 & 0 \\
\hline & $\mathrm{Cl}$ & 1 & 1 & 0 & 0 & 1 & 0 & 0 & 1 & 0 & 0 \\
\hline & Knife & 1 & 1 & 0 & 0 & 1 & 0 & 0 & 0 & 1 & 0 \\
\hline Total & & 20 & 20 & 0 & 0 & 18 & 2 & 0 & 18 & 2 & 0 \\
\hline
\end{tabular}

CO Carcass outside, Cl Carcass inside, Sen. Sensitive, Res. Resistant, Int. Intermediate resistant

during evisceration. However, of all 72 samples of carcass inside samples taken during this study only $1(1.39 \%)$ was found to be positive for E. coli O157:H7 from sheep, with no significant importance.

The level of carcass outside contamination was considered as an outcome variable taking skin swab, fecal sample and knife swab as risk factors for carcass contamination. However, assessments using logistic regression analysis as well as Chi square test did not show significant associations between carcass contamination and the risk factors were (Table 5).

In contrast, the previous study on another export abattoir in Modjo showed a significant association with these risk factors except for carcass in contacts. This shows that the implementation of HACCP system in the abattoir has reduced the risk of contamination of carcasses during the slaughtering operation, as compared to the previous study with no HACCP system implemented. Even if no information is obtained about the slaughtering practice during previous study, as it was observed during this study the abattoir management and MoARD takes the credit for proper implementation of strict prevention methods and careful handling on the slaughtering line.

Results of this study were supported by other studies for the absence of association between hide prevalence and carcass contamination [21]. However, in those reports hide prevalence of E. coli O157:H7 was much lower than fecal prevalence. Possible explanations for this apparent discrepancy might be a difference in the selection of skin sampling site. A difference in the sampling site could affect isolation rate of a given pathogen. For example, Reid et al. [3] isolated 3.3\% from rump, 4.4\% from flank and 22.2\% from brisket of E. coli O157:
$\mathrm{H} 7$ by swabs on the same animals. This might be due to difference in the survival rates of $E$. coli O157: $\mathrm{H} 7$ in different sites of the skin of animals. Moreover, it has been indicated that one site on the skin may have higher levels of contamination than the others and, therefore, posing greater risks for carcass contamination.

On the other hand, associations of these risk factors with carcass contaminations were also reported from different parts of the world: associations with feces by Elder et al. [21, 48] and Griffin et al. [49]; and with skin by Reid et al. [3]. On the contrary, absence of association between hide prevalence and carcass contamination was reported by Elder et al. [21], and in those reports hide prevalence of $E$. coli O157:H7 was much lower than fecal prevalence. Possible explanations for this apparent discrepancy might be a difference in the selection of skin sampling site as mentioned above.

The higher prevalence of $E$. coli O157:H7 observed from skin swabs $(6.94 \%)$ than from fecal samples of sheep $(8.33 \%)$ disagrees with the report of Elder et al. [21], where they reported higher prevalence in feces $(28 \%)$ than on hides $(11 \%)$. The skin of animals could have a number of sources to carry E. coli O157:H7 such as the soil, feed, water, feces etc. but animals could shed E. coli O157:H7 seasonally in their feces and as a result might be negative for the organisms on sampling time. The skin of a given animal could be contaminated by fecal sources from themselves and other animals. Therefore, during transportation and in the lairage cross contamination of skins could occur due to a more close contact of animals and as result an increase in the apparent prevalence of $E$. coli $\mathrm{O} 157: \mathrm{H} 7$ on skin relative to feces could be observed. 
Although pressure washing was applied on the carcass and also knives were immersed in hot water between trimming of successive carcasses, E. coli $\mathrm{O} 157: \mathrm{H} 7$ was isolated in one of the knives. This indicates that this could be a critical point for carcass contamination and the prevention methods should be applied strictly; in this aspect adequate temperature should be used for sterilization of knives. In addition, while transferring carcasses manually by carrying from the overhead rails to the chilling room, bacterial recontamination might occur and spread from one carcass to others.

In addition, no positive carcasses were found from animals that were E. coli $\mathrm{O} 157: \mathrm{H} 7$ negative from their fecal, mucosal swab or skin samples. This finding strongly suggests the presence of carcass cross-contamination in the abattoirs. Reducing the amount of E. coli $\mathrm{O} 157: \mathrm{H} 7$ in live sheep and goats will likely lower contamination not only of meat but also of other food and water supplies that are exposed to sheep and goat fecal matter.

Similarly, the level of carcass inside contamination was considered as an outcome variable taking skin swab, fecal sample and knife swab as risk factors for carcass contamination. However, such contamination sources were not significantly associated with carcass contamination and $E$. coli $\mathrm{O}$ 157: $\mathrm{H} 7$ status of the risk factors.

\section{Detection of virulence genes on the isolates}

Shiga toxins, encoded by $s t x 1$ or $s t x 2$ genes, the pathogenicity island LEE, coding for factors causing for attaching and effacing lesions and the enterohaemolysin encoded by $e h x A$ gene are the major virulence factors found in $E$. coli $\mathrm{O} 157: \mathrm{H} 7$ [50, 51]. In the current study, half of the positive isolates were having two of the virulence genes tested.

In our finding seven of the isolates from goat and sheep had both eaeA and stx2 genes and three of them were with only the eaeA gene (Table 7), but none of them show the $s t x 1$ gene. The recovery of eaeA positive organisms at higher rate in mucosal swabs than in fecal samples shows that the intimin gene encoded by eae $A$ helps the organism to adhere tightly to the intestinal mucosal. Thus, fecal samples are not as good as mucosal swabs in isolating the organism. The higher numbers of isolates of this study showing the virulence genes with a lower prevalence, as compared to only one isolate, in the previous study in this area, with higher prevalence, are needed to be given an attention. In addition, it indicates the dynamicity of the bacteria over years and the capability of it to evolve and adapt to new environments. In other studies undertaken in Greece [42] only stx 2 from a single E. coli $\mathrm{O} 157: \mathrm{H} 7$ isolate was obtained from goat feces. Of the total 33 isolates in France [35] from sheep, only five of the isolates carried the $s t x 1$ and $s t x 2$. The identification of these virulence genes in this study from half the isolates indicates the potential of small ruminant carcass as source of E. coli O157:H7 for human infections in the country and its effect to the growing meat export market. It also suggests the need for further detailed epidemiological studies on E. coli $\mathrm{O} 157: \mathrm{H} 7$ in Ethiopia involving different export abattoirs and species of animals.

\section{Antimicrobial susceptibility of the isolates}

This study showed complete susceptibility of all isolates to one of the antimicrobial used, Norfloxacin (NOR) and variable levels of resistance towards the other antibiotics tested. Hiko et al. [12], Faris and Mekonen [52] and Lula [53] have reported antimicrobial resistance patterns of $E$. coli $\mathrm{O} 157: \mathrm{H} 7$ isolates, from animal and human sources, in Ethiopia. Only three antibiotics namely Norfloxacin, Ceftazidime and Polymyxin B were seen to be effective against this bacteria but all the rest of the antibiotics used have no effect on it. A wider antibiotic resistance seen in this study is similar to other authors' explanations about the bacteria [54-56]. This higher percentage of resistance might be due to presence of only few isolates tested for susceptibility compared to overall study population and variability of resistant gene within isolates for particular antimicrobials. Although there is difference in the sources of isolates, the $20(100 \%)$ of present isolates resistant to one or more antibiotics were higher than $41 \%$ of those previously tested isolate by Mora et al. [16] in Spain from human, cattle, ovine and food. Moreover, the overall drug resistant in the present study is much more higher than those isolates tested by Wilkerson et al. [56], forty-four (6.6\%) of 663 of bovine and 29 (12.2\%) 238 of human E. coli O157: H7 isolates from feedlots in the mid-western United States and the Public Health Departments of Washington, Oregon, Nevada, Wisconsin, Georgia, and Illinois states. This could be due to difference in the type of samples, number of isolate and genetic variation of the isolate among different geographical areas. Whereas the susceptibility of all the isolates to Norfloxacine, and 18 of them for polymixin B and Ceftazidime encourages hope for finding the most effective antibiotic therapy against $E$. coli O157: H7.

\section{Conclusions}

In conclusion, E. coli O157: $\mathrm{H} 7$ was detected from the feces, skin, intestinal mucosal swab and carcasses of sheep and goats and knife at export abattoir. This pathogen was isolated from carcasses, from the inside and outside parts that indicated the presence of carcass contamination during slaughter operations. Thus, interventions to reduce the occurrence of E. coli $\mathrm{O} 157: \mathrm{H} 7$ and reduce carcass contaminations were not absolute even if the prevalence are lower in this study. Prevalence of E. coli O157:H7 is higher in sheep than goats with statistically significant difference. The presence of eaeA and stx 2 positive E. coli 
O157:H7 in sheep and goats carcass should be given attention. Thus, in addition to cattle, sheep and goats could serve as source of human infection.

\section{Acknowledgements}

We are extremely indebted to Professor Dr. Bruno Goddeeris, from the Catholic University of Leuven who led the VLI R-UOS project, for facilitation of the overall research grant, continuous support and follow up. We thank the Microbiology Laboratory, College of Veterinary Medicine and Agriculture, Addis Ababa University, for availing their laboratory facility and equipment. The authors also would like to extend their gratitude to the staff of the export of abattoir in Modjo for their collaboration during sampling.

\section{Authors' contributions}

AT and SA designed the proposal, participated in the coordination and management of the study, collected, tested and analyzed the data and drafted the article; EC, TST study design, scientific advising of the overall work and edition of article. TST also participated in molecular part of the work and correspondence of the article's publication. All authors read and approved the final manuscript

\section{Funding}

This research was financially supported by VLIR-UOS project no. "ZEIN 2010 PR 372" "Promotion of the PhD program in veterinary public health at the Faculty of Veterinary Medicine", Belgium during sample collection and laboratory analysis part of the work.

\section{Availability of data and materials}

Not applicable

\section{Ethics approval and consent to participate}

This study was conducted on an abattoir. In addition, the research proposal was publicly defended and conduct of the experiment was permitted by the office of Graduate programs at College of Veterinary Medicine and Agriculture, Addis Ababa University, Debre Zeit/ Bishoftu, Ethiopia.

\section{Consent for publication}

Not applicable

\section{Competing interests}

No conflict of interest declared.

\section{Author details}

'Veterinary Drug and Feed Administration and Control Authority of Ethiopia (VDFACA), Veterinary drug registration, certification and administration directorate director, Addis Ababa, Ethiopia. ${ }^{2}$ Department of Microbiology, Immunology \& Veterinary Public Health, College of Veterinary Medicine and Agriculture, Debre Zeit/ Bishoftu, Ethiopia. ${ }^{3}$ Faculty of Veterinary Medicine, Gent University, Salisburylaan 133, B-9820 Merelbeke, Belgium. ${ }^{4}$ Institute of Biotechnology, Addis Ababa University, Addis Ababa, Ethiopia.

\section{Received: 24 April 2019 Accepted: 30 August 2019}

\section{Published online: 12 September 2019}

\section{References}

1. Busani L, Cigliano A, Taioli E, Caligiuri V, Chiavacci L, Dibella C, et al. Prevalence of Salmonella enterica and Listeria monocytogenes contamination in foods of animal origin in Italy. J Food Prot. 2005;68:1729-33.

2. Hansson I, Hamilton C, Ekman T, Forslund K. Carcass quality in certified organic production, compared with conventional livestock production. J Vet Med. 2000:47:111-20.

3. Reid C, Small A, Avery S, Buncic S. Presence of foodborne pathogens on cattle hides. Food Control. 2002;13:411-5.

4. Hajian S, Rahimi E, Mommtaz H. A 3 year study of Escherichia coli O157:H7 in cattle, camel, sheep, goat, chicken and beef minced meat. Int Conf Food Eng Biotechnol. 2011;9:163-5.

5. Fratamico P, Smith J. Escherichia coli infections. In: Riemann H, Cliver D, editors. Food borne infections and intoxications. 3rd ed. New York: Elsevier science; 2006

6. Cleary J, Lai LC, Shaw RK, Straatman-Iwanowska A, Donnenberg MS, Frankel $G$, Knutton S. Enteropathogenic Escherichia coli (EPEC) adhesion to intestinal epithelial cells: role of bundle-forming pili (BFP), EspA filaments and intimin. Microbiology. 2004;150:527-38.

7. Chapman P. Cerda'n Malo a, Ellin M, Ashton R, Harkin M. Escherichia coli O157 in cattle and sheep at slaughter, on beef and lamb carcasses and in raw bee and lamb products in South Yorkshire. Int J Food Microbiol. 2001;64:139-50.

8. Battisti A, Lovari S, Franco A, Diegidio A, Tozzoli R, Caprioli A, et al. Prevalence of Escherichia coli $\mathrm{O} 157$ in lambs at slaughter in Rome, Central Italy. Epidemiol Infect. 2006;134:415-9.

9. CDC (Centers for Disease Control and Prevention). Outbreaks of Escherichia coli 0157:H7 associated with petting zoos -North Carolina, Florida, and Arizona, 2004 and 2005 department of health and human services. MMWR. 2005;54:1277-80.

10. Riley LW, Remis RS, Helgerson SD, McGee HB, Wells JG, Davis BR, et al. Hemorrhagic colitis associated with a rare Escherichia coli serotype. N Engl 」 Med. 1983;308:681-5.

11. Raji MA, Minga U, Machangu R. Current epidemiological status of enterohaemorrhagic Escherichia coli O157:H7 in Africa. Chin Med J. 2006;1 19:217-22.

12. Hiko A, Asrat D, Zewde G. Occurrence of Escherichia coli O157:H7 in retail raw meat products in Ethiopia. J Infect Dev Ctries. 2008;2(5):389-93.

13. Mersha G, Asrat D, Zewde BM, Kyule M. Occurrence of Escherichia col O157:H7 in faeces, skin and carcasses from sheep and goats in Ethiopia. Lett Appl Microbiol. 2010;50:71-6.

14. Zhang X, McDaniel AD, Wolf LE, Keusch GT, Waldor MK, Acheson D. W. Quinolone antibiotics induce Shiga toxin-encoding bacteriophages, toxin production, and death in mice. J Infect Dis. 2000;181:664-70.

15. Meng J, Zhao S, Doyle MP, Joseph SW. Antibiotic resistance of Escherichia coli O157:H7 and O157: NM from animals, food, and humans. J Food Prot. 1998;61:1511-4.

16. Mora A, Blanco JE, Blanco M, Alonso MP, Dhabi G, Echeita A, et al. Antimicrobial resistance of Shiga toxin (verotoxin)-producing Escherichia coli 0157:H7 and non-O157 strains isolated from humans, cattle, sheep and food in Spain. Res Microbiol. 2005;156:793-806.

17. Tadesse DA, Zhao S, Tong E, Ayers S, Singh A, Bartholomew MJ, et al. Antimicrobial drug resistance in Escherichia coli from humans and food animals, United States, 1950-2002. Emerg Infect Dis. 2012:18(5):741-9.

18. Heuvelink A, Flam V, de Boer E. Isolation and characterization of Verocytotoxinproducing Escherichia coli 0157 strains from Dutch cattle and sheep. J Clin Microbiol. 1996;36:878-82.

19. IPMS (Improving Productivity and Market Success): Ada'a-Liben Woreda pilot learning site diagnosis and program design. Addis Ababa: LLRI (International Livestock Research Institute); 2005. p.1-8.

20. Thrusfield M. Veterinary epidemiology. 3rd ed. London: Blackwell Science Ltd; 2005.

21. Elder R, Keen J, Siragusa G, Barkocy G, Koohmaraie M, Laegreid W. Correlation of Enterohemorrhagic Escherichia coli 0157 prevalence in feces, hides and carcasses of beef cattle during processing. Proc Natl Acad Sci. 2000;97:2999-3003.

22. Mc Evoy J, Doherty A, Sheridan J, Thomson-Carter F, Garvey P, McGuire L, et al. The prevalence and spread of Escherichia coli 0157:H7 at a commercial beef abattoir. J Appl Microbiol. 2003;95:256-66.

23. NPH (National Public Health Service for Wales) Detection of Escherichia coli 0157 by Automated Immunomagnetic Separation. Standard Method. Issued by Standards Unit, Evaluations and standards laboratory with the regional food, Water and Environmental Coordinators Forum. Wales: SOPs from the Health Protection Agency; 2006. p. 1-15.

24. ISO (International Organization for Standardization) 16654. Microbiology of Food and Animal Feeding Stuffs - Horizontal Method for the Detection of Escherichia coli 0157; 2001. p. 1-13.

25. Chapman P. Isolation, identification and typing of Vero cytotoxin-producing Escherichia coli O157. PHLS Microbiol Digest. 1994;11:13-7.

26. United States Department of Agriculture (USDA), Office of Public Health and Science (OPHS), Food Safety and Inspection Service (FSIS). Detection, Isolation, and Identification of E. coli 0157:H7 and O157: NM from Meat Products Microbiology Laboratory Guidebook Notice of Change. Limits of Detection to Meet the Requirements of ISO 17025; 2002. p. 1-13.

27. OIE (Office for international des epizootics) Verocytotoxigenic Escherichia coli. Manual of Diagnostic Tests and Vaccines for Terrestrial Animals. Geneva. Updated: 23.07.2004. Part 2.Section 2.10.3. http://www.oie.int/eng/ norms/manual (A-0007) (2004). Accessed on 2013

28. Inat G, Siriken B. Detection of Escherichia coli $\mathrm{O} 157$ and Escherichia coli 0157:H7 by the immunomagnetic separation technique and stx 1 and st $x 2$ genes by multiplex PCR in slaughtered cattle in Samsun Province. Turkey $J$ Vet Sci. 2010;11:321-6. 
29. Gun H, Yilmaz A, Turker S, Tanlasi A, Yilmaz H. Contamination of bovine carcasses and abattoir environment by EscherichiacoliO157:H7 in Istanbul. Int J Food Microbiol. 2003:84:339-44.

30. CSLI. Performance standards for antimicrobial disc and dilution susceptibility tests for bacteria isolated from animals. 3rd ed. Wayne: Approved standard; 2008.

31. SPSS (statistical package for the social sciences). Inc. SPSS for windows (version 11.5.0). Chicago: IBM ${ }^{\circledast}$ SPSS Statistics; 2002.

32. Blanco M, Blanco J, Mora A, González E, Bernárdez M, Alonso M, et al. Vero toxin-producing Escherichia coli (VTEC) in Spain: prevalence, serotypes, and virulence genes of 0157:H7 and non-O157 VTEC in ruminants, raw beef products, and humans. Exp Biol Med. 2003;228:345-51.

33. Sargeant J, Smith D. The epidemiology of Escherichia coli 0157:H7. In: Torrence M, Isaacson R, editors. Microbial food safety in animal. lowa State Press: Agriculture Current Topics; 2003. p. 131-74.

34. Bhandare S, Sherikar A, Paturkar A, Waskar V, Zende R. A comparison of microbial contamination on sheep/goat carcasses in a modern Indian abattoir and traditional meat shops. Food Control. 2007;18:854-8.

35. Lenahan M, O'Brien S, Kinsella K, Sweeney T, Sheridan J. Prevalence and molecular characterization of Escherichia coli 0157:H7 on Irish lamb carcasses, fleece and in Faeces sample. J Appl Microbiol. 2007;103:2401-9.

36. Paiba G, Gibbens J, Pascoe S. Fecal carriage of Verocytotoxin-Producing E. coli O157 in cattle and sheep at slaughter in Great Britain. Vet Rec. 2002;150:593-8.

37. Gencay YE. Sheep as an important source of E. coli O157/O157:H7 in Turkey. Vet Microbiol. 2014;172:590-5.

38. Kudva I, Hatfield P, Hovde C. Escherichia coli O157:H7 in microbial Flora of sheep. J Clin Microbiol. 1996;34:431-3.

39. Sidjabat-Tambunan H, Bensink J. Vero toxin-producing Escherichia coli from the Faeces of sheep calves and pigs. Aust Vet J. 1997;75:292-3.

40. Johnsen G, Wasteson Y, Heir E, Berget I, Herikstad H. Escherichia coli 0157: H7 in feces from cattle, sheep and pigs in the southwest part of Norway during 1998 and 1999. Int J Food Microbiol. 2001;65:193-200.

41. Synge B, Hopkins G. Studies of Verotoxigenic Escherichia coli O157 in cattle in Scotland and association with human cases. In: Karmali M, Goglio A, editors. Recent advances in Verocytotoxin producing Escherichia coli infections. New York: Elsevier Science; 1994. p. 65-8.

42. Dontoroua A, Papadopouloua C, Filioussisb G, Apostoloua I, Economoua V, Kansouzidouc A. Isolation of a rare Escherichia coli 0157:H7 strain from farm animals in Greece. Comp Immunol Microbiol Infect Dis. 2004;27:201-7.

43. Keen J, Durso L, Meehan T. Isolation of salmonella enterica and Shigatoxigenic Escherichiacoli 0157 from feces of animals in public contact areas of United States zoological parks. Appl Environ Microbiol. 2007;73:362-5.

44. Bastian S, Carle I, Grimont F, Grimont P. Diversity of Shiga toxin-Producing E. coli in herds of dairy cows and goats. Acta Clin Belg. 1999;54:49-50.

45. Fagan P, Hornitzky M, Bettelheim K, Djordjevic S. Detection of Shiga-like toxin (stx1 and stx2), Intimin (eaeA), and Enterohemorrhagic Escherichia coli (EHEC) Hemolysin (hly) genes in animal Faeces by multiplex PCR. Appl Environ Microbiol. 1999:65:868-72.

46. Islam MZ, Musekiwa A, Islam K, Ahmed S, Chowdhury S, Ahad A, Biswas PK. Regional variation in the prevalence of $E$. coli 0157 in cattle: a meta-analysis and meta-regression. PLoS One. 2014;9(4):e93299.

47. McPherson AS, Dhungyel OP, Ward MP. Comparison of recto-anal mucosal swab and faecal culture for the detection of Escherichia coli 0157 and identification of super-shedding in a mob of merino sheep. Epidemio Infect. 2015;1(13):1-10.

48. Gansheroff L, O'Brien A. Escherichia coli O157:H7 in beef cattle presented for slaughter in the U.S. higher prevalence rates than previously estimated. Proc Natl Acad Sci. 2000;97:2959-61.

49. Griffin PM, Olmstead LC, Petras RE. Escherichia coli O157:H7-associated colitis: a clinical and histological study of 11 cases. Gastroenterology. 1990; 99:142-9.

50. IFT. Expert report on emerging microbial food safety Issues. Ulster/Stone: Implications for control in the 21st Century, S. Lowry/Univ; 2003. p. 1-12.

51. Chahe A, China B, Mainil J, Daube G. Prevalence of Enterohaemorrhagic Escherichia coli from serotype 0157 and other attaching and effacing Escherichia coli on bovine carcasses in Algeria. J Appl Microbiol. 2006;101:361-8.

52. Faris G, Mekonen E. Prevalence and antibiotic susceptibility of E. coli strains in UTI: Prevalence and antibiotic susceptibility of E. coli strains amongst patients with complaints of urinary tract infection. LAP LAMBERT Academic Publishing: 2012

53. Lula W. Prevalence and antibiotic susceptibility of campylobacter species and Escherichia coli O157:H7 in bovine, ovine and caprine carcass in
Diredawa. Ethiopia: Thesis Department of Microbiology, Haramaya University Haramaya, Ethiopia; 2011.

54. Schroeder C, Zhao C, Debroy C, Torcolini J, Zhao S, White D. Antimicrobial resistance of Escherichia coli 0157 isolated from humans, cattle, swine, and food. Appl Environ Microbiol. 2002;68:576-81.

55. Bettelheim KA. Biochemical characteristics of Escherichia coli. In: Gyles CL, editor. Escherichia coli in domestic animals and humans. Wallingford: CAB International; 1994. p. 3-30.

56. Wilkerson C, Kirk N, Roberts M. Antibiotic resistance and distribution of tetracycline resistance genes in Escherichia coli 0157:H7 isolates from humans and bovines. Antimicrob Agents Chemother. 2004:48:1066-7.

\section{Publisher's Note}

Springer Nature remains neutral with regard to jurisdictional claims in published maps and institutional affiliations.
Ready to submit your research? Choose BMC and benefit from:

- fast, convenient online submission

- thorough peer review by experienced researchers in your field

- rapid publication on acceptance

- support for research data, including large and complex data types

- gold Open Access which fosters wider collaboration and increased citations

- maximum visibility for your research: over $100 \mathrm{M}$ website views per year

At BMC, research is always in progress.

Learn more biomedcentral.com/submissions 